\title{
ART AND ARCHAEOLOGY CLOSE ENCOUNTERS OF THE THIRD KIND
}

\author{
Üftade MUŞKARA \\ Kocaeli University, Turkey \\ uftade.muskara@kocaeli.edu.tr \\ https://orcid.org/0000-0002-4709-8821 \\ Oylum TUNÇELLI \\ Kocaeli University, Turkey \\ oylum.tuncelli@kocaeli.edu.tr \\ https://orcid.org/0000-0002-0790-7655 \\ Serpil ŞAHIN \\ Kocaeli University, Turkey \\ serpilsahin2425@gmail.com \\ https://orcid.org/0000-0002-0099-7336
}

\begin{abstract}
Art and archaeology have a growing interaction, which is expressed mainly in displaying the material culture of ancient civilizations. The post-modernist concept suggests that art is for everyone. Likewise, archaeologists recognize the idea that archaeological narratives are supposed to be everyone to understand and enjoy. Today, many museum displays and special exhibitions consist of contemporary design features of art. The technology-driven exhibition techniques applied in the "Curious Case of Çatalhöyük" exhibition and Göbeklitepe Animation Center to increase the perception of visitors establish the basis of the study. The paper examines the backgrounds of the relation between two disciplines by "digging" up the history of archaeological theories and analyzing main art movements corresponding to a period from Dadaism to contemporary art. Archaeological storytelling of history and culture using post-modern rhetoric is defined as the "close encounter." The interactive display provides new directions in the visual reconstructions of past societies. We proposed that the Çatalhöyük exhibition and Göbeklitepe Animation Center are among the best examples of the new approach for presentation in archaeology.
\end{abstract}

Keywords: Art and Archaeology, Digital Art, Post-Modernism, Çatalhöyük, Göbeklitepe, Museology

\section{SANAT VE ARKEOLOJI: ÜÇÜNCÜ TÜRDEN YAKINLAŞMALAR}

\section{Öz}

Sanat ve arkeoloji, özellikle eski uygarlıkların maddi kültürünün sergileme biçimlerinde giderek artan bir etkileşime içindedirler. Post-modern yaklaşım, sanatın herkes için olduğunu 
öne surer. Benzer şekilde, arkeologlar da arkeolojik anlatılarının herkesin anlayıp zevk alabileceği biçimde sunulabileceği düşüncesini geliştirmektedirler. Günümüzde birçok müze ve özel sergi sanatın çağdaş tasarım özellikleriyle oluşturulmaktadır. Teknoloji odaklı sergileme teknikleri ile ziyaretçilerin algısını arttıran "Bir Kazı Hikayesi: Çatalhöyük” sergisi ve Göbeklitepe Canlandırma Merkezi'nde kullanılan uygulamalar çalışmanın temelini oluşturmaktadır. Makalede, arkeolojik kuramların tarihini "kazarak" ve Dadaizm'den çağdaş sanata, belirli ana sanat akımlarını analiz ederek iki disiplin arasındaki ilişkinin geçmişini incelemektedir. Genellikle dijital sanat eserlerinde gözlemlediğimiz post-modern retorik kullanarak yapılan arkeolojnin sunum yöntemi "yakınlaşma" olarak tanımlanmıştır. Etkileşimli sergileme geçmiş toplumların yeniden canlandırılmalarında yeni yaklaşımlar sağlamaktadır. Çatalhöyük sergisinin ve Göbeklitepe Canlandırma Merkezi'nin, arkeolojideki sergileme yöntemlerinde yeni yaklaşımın en iyi örnekleri arasında yer aldığını önermekteyiz.

Anahtar Kelimeler: Sanat ve Arkeoloji, Dijital Sanat, Post-Modernizm, Çatalhöyük, Göbeklitepe, Müzecilik

\section{INTRODUCTION}

The principal idea of this study has been formed when we visited the 'Curious Case of Çatalhöyük' exhibition in 2018 and the Göbeklitepe archaeological site in 2019. As the authors from the different educational background, we found the design concepts of Çatalhöyük and Göbeklitepe were strikingly different from the traditional style of displaying archaeological objects. Indeed, archaeology itself was at the display as an event and as an engaging object. Contemporary exhibition tools were applied to attract visitors that we usually encounter at an art museum.

Practices of art collections and connoisseurship strongly influenced the emergence of archaeology. Consequently, archaeological objects were depicted as "artistic" identities, and the visitors were identified merely as audiences. The typical way of seeing later was reshaped due to transformation in society, art, and technological developments. By the $90 \mathrm{~s}$, as digital works of art became popular, the connection between object of art and visitors has evolved into an interactive dimension. Therefore, visiting a museum or an art exhibition became an alternative way of entertainment. As the importance of the "narrative" of archaeological objects was realized, and exhibitions focused on storytelling, the museums started to apply new media methods for displaying and reconstructing the past. As postmodernity indicates that art is for everyone, archaeologists seem to favor the idea that the narratives of archaeology are supposed to be everyone to understand and enjoy. Then archaeology adopted the conceptual approaches of art once again, but this time in a more comprehensive way, including the practices and the idea behind them. Consequently, the title refers to Astrophysicist J. Allen Hynek's classifications of UFO incidents, as the definition of "the third kind" is actual contact with art.

In this study, we define the hypothesis of research as:

- The interaction between art and archaeology has been improved

- The exhibition ways in archaeology is inspired by digital art

- The digital tools has increased the sense of curiosity

- New ways have a positive effect on education at museums

The paper aims to describe the evaluation of the current state of the interrelationship between art and archaeology. Thereby, we investigated the evolution of interaction and analyzed the similarities in the two disciplines' design discourse. In the first chapter, culture-historical archaeology, processual archaeology, and post-processual archaeology were reviewed. The major art movements, including Dadaism, post-modernism, and contemporary art, were discussed accordingly to explore the developments that have influenced the interactive exhibition concept. The framework of the new museology was also discussed regarding post-modernism and the application of new media 
technologies. The foundations of the design concepts at Çatalhöyük and Göbeklitepe exhibitions were presented in the final chapter. The way digital tools transform the essential elements of the exhibition were examined based on the application of digital media at Göbeklitepe animation center and Curious Case of Çatalhöyük' exhibition. Consequently, the study investigates the new generation methods of education, perception, and experience for transferring the meaning of cultural things to audiences.

\section{CULTURE-HISTORICAL ARCHAEOLOGY, DADAISM, AND READY-MADE}

\section{CULTURE-HISTORICAL ARCHAEOLOGY}

The emergence of archaeology as a transition from "Cabinet de curiosités" to a scientific discipline was tied to intellectual developments in the 18th century. The evolutionary debate, which was related to the theory of cultural evolution proposed by Lewis Henry Morgan, influenced the genesis of archaeology (Bapty and Yates, 1990: 261). By the 19th, Nationalism reflected changes in society through industrialization and increasing identity in Europe. Hence, this period's archaeological approach called culture-historical archaeology (also known as old archaeology) could be best described regarding cultural evolution, Nationalism, ethnic identity. Nationalism and ethnicity were the driving force for the archaeologists to search their roots in material culture and develop a narrative for Western -European- art considered to be bound to the Greek and Roman cultures. In the meantime, there was also an interest in tracing the origins of European civilization in the Middle East to support religious views (Trigger, 2007: 229).

Through the first half of the 20th century, archaeology in Europe followed racist attitudes. The belief that man's behavior could be predicted by race and by physical characteristics influenced the rhetoric of archaeological interpretation. The racist approach also benefited from the invention of photography. Photography's ability to measure inspired travelers and scientists to develop methodologies to define racial typologies (Zamorano, 2011: 430). Whereas Cesare Lombroso's assumption that suggested criminals were distinguished from non-criminals by multiple physical anomalies founded the base of criminology. Multiple physical "anomalies" were defined through postmortem examinations and anthropometric studies of criminals to distinguish criminals from non-criminals. One of the first executors of this theory, Ottoman Sultan Abdühamid II (1842-1912), established a "fotoğrafhane" photographer's studio- in 1884 to produce pictures of prisoners. He employed the photo album to decide whom he would choose for the amnesty granted for the 25th anniversary of his accession (Özendes, 2017: 32).

In this historical context, culture-historical archaeology's main characteristic was its definition of culture "as a set of ideas transmitted in the form of ideal norms or mental templates" (Lyman and O'Brien 2004). Lewis Binford described this conception as normative theory. According to Michael J. O'Brien and R. Lee Lyman, Binford created the normative theory to underline the differences between "old" and "new" archaeology (2004: 389-391). The culture-historical interpretation was based on the attribution of cultural change detected by material culture to either diffusion or migration. The methodology involved visual analyzing, measuring, and statistically evaluating material remains according to shape and patterns and forming seriation to perceive the difference in material culture and set regularities for culture.

By the late 1920s, Russian archaeologists developed a new understanding of archaeological interpretation (Trigger, 2007: 384). They questioned the reasons for cultural and social changes in terms of the internal dynamics in contrast to explanations depending on the external dynamics by European archaeologists. Meantime, British and American anthropologists generated a similar approach, including the effort to define a reason for the changes in social systems (Trigger, 2007: 385). The later developments could be considered the basis for the processual-new archaeology appearing in the USA in the 1960s. 


\section{DADAISM AND READY-MADE}

While the pioneers of archaeology followed the current theories and social approaches, art philosophers developed a new discourse due to the shift in lifestyle in the post-industrial society and World War I. For instance, John Ruskin and William Morris claimed that contemporary art and artists were apart from mundane life and culture. They interpreted the social and economic problems of the industrial revolution, referring to artistic production. Morris defined art as beneficial for everyone and should be shared (Woods Dick, 1984: 1-3).

The avant-garde art movement Dadaism emerged in 1916 in Zurich. Dada artists including Hugo Ball, Tristan Tzara, Max Ernst, and Marcel Duchamp were concerned with the brutality of World War I and the results of industrialization, technological development, and modernization. Their manifesto, written by Tzara, was a protest, act, and art of destruction and blowing up reasoning (Antmen, 2009: 122). They often declared that "Dada means nothing," but it stood for life. Dadaism was against reason, which reflects nationalist politics (Elder, 2015: 116). Archaeology was also mentioned within the Dada Disgust: "...DADA; abolition of memory: Dada; abolition of archaeology: DADA; abolition of prophets: DADA; abolition of the future..."

Dada artists, who rejected all forms of social values denied life, turned onto randomness and improvisation. Instead of hoaxes of reason and rational choice, they aimed to create new and absurd forms of art to show alternative visions of the world as they were refusing traditional representations. Therefore, the text of Dadaist Disgust was an objection to social approaches and organization that restrained creativity. Archaeology, along with memory and prophets showing the limitations for past and future, were mentioned in this sense. Jeffrey Schnapp et al. (2004: 4) evaluated the part of the text relating to archaeology with regarding modern - modernist archaeology:

"...the abolition of archaeology has nested within it a positive counterproposal. It stands as the precondition for another (and even othering) archaeology loosely affiliated both with Freud's tracking of subterranean psychic and somatic intensities, and with an ongoing modern preoccupation, extending from Nietzsche through Artaud and Bataille, with tapping into "prehistoric" instinctualisms, violence, savagery, sacrifice, and sacrality. Instead of feeding necrophilia, this modernist archaeology purports to operate in the service of life."

The most important difference of Dada artists, who inspired with spontaneity used collage and photomontage techniques with unorthodox materials, was their aim to remove the borders between art and life as Bauhaus school. Marcel Duchamp produced "ready-made" artworks using ordinary objects to investigate the notion of art and criteria for aesthetic taste and to transform art into the process of thought and creativity. He invented this new category of artworks, ready-mades, as taking the idea of found object - the objet trouvé one step further.

Although Dadaism was active for a short period, 1916 to roughly 1924, it had been one of the most predominant and influential art movements in the 20th century. It was the precursor of conceptual art approaches that emerged in the 1960s.

\section{POST-MODERNISM, PROCESSUAL ARCHAEOLOGY AND POST-PROCESSUAL ARCHAEOLOGY}

\section{POST-MODERNISM}

Post-modernism is a term that broadly describes the reaction against modernism. David Harvey argued that post-modernism reflecting skepticism and suspicion of reason in the post-industrial revolution era was consisted of "a great variety of developments in recent progressive politics - such as feminism, anti-racism, and queer activism - by virtue of their emphases upon an apparently relativistic politics of positionality, proceed in the spirit of these recent processes of capitalist development" (Harvey, 1989: $5)$. 
French structuralist and post-structuralist theorists Roland Barthes, Michel Foucault, and JeanFrancois Lyotard criticized the notion of objectivity and concerned with the ambiguity in language. Drawing upon Ferdinand de Saussure's linguistic theories, they believed that knowledge and perception were based on how fundamental concepts were defined. Feminist discourse, which was using the post-structuralist linguistic theories, aimed to defeat the modernist approach and reveal the importance of the feminist art movement emerging in the late 1960s (Şahiner, 2008: 194-196). Feminism inspired feminist, queer, and gender archaeology in the 1970s. Their argument for the patriarchal systems that dominated in the past as a reflection of gender stereotypes was indeed tied to narratives of the feminist movement (Arnold and Wicker 2001).

While modernism was based on idealism and technological progress created by industrialization, postmodernism could be characterized by the age of electronic media. In this context, we should recall Marshall McLuhan's Gutenberg Galaxy: The Making of Typographic Man regarding digital-new media (1962). In his work, McLuhan explained the shift in media and described four eras of 1) oral tribal culture, 2) preliterate culture that used phonetic alphabet and manuscript, 3) the age of print and mass production, 4) the age of electronic media. According to McLuhan, the real evil in the story was the age of print. When print was created in the visually hypnotized society, the previous harmony of the senses was interrupted by mass production. In the electronic age, by contrast, the community went back to oral tribal culture conditions. The modern individual started to communicate and interact together. His definition of "Global Village" was indeed a positive conception. However, in reality, post-modernist capitalism has diffused consumptive consciousness using mass media. Consequently, post-modern artists by the 1980s questioned the new understanding of life, which depended on consumption, and attempted to analyze signs and symbols of the stereotyped standard of judgment and aimed to redirect them.

Post-modernism inspired many disciplines, including art, architecture, and archaeology. According to the theorists such as Douglas Crimp, Hal Foster, Rosalind Krauss, and Craig Owens, post-modern art refused to recognize the authority in any social institutions and strict traditional practices (Antmen, 2009: 277). Post-modernism broke the established rules about style and shape integrity and collapsed the cult of individual-artist. It introduced a new era of dissident art practices and models as challenging with modernist art and art markets. Mixing different artistic styles and media created a conceptual and interdisciplinary sense of art and formed many art reactions and movements, including process art, mail art, body art, fluxes, performance, and video-art.

Conceptual artists gave more importance to the concept of artwork rather than the finished art object. They used any materials, which were most appropriate to put their idea beside the traditional materials. Found objects such as footages, sound records, brochures, newspapers, or journal articles were modified and presented as art. They invited visitors to see, think, examine, and complete their work. Technological developments influenced artists in their choice of artwork materials. Digital art, which was made or presented using digital technology, emerged in the early 1980s. Since then, artists have applied computer designs that provide an alternative way of producing and visualizing art to express their perceptions and perform their experiments.

However, by the late 20th century, essential philosophers criticized the social and cultural transformation induced by post-modernism. Jean Baudrillard provided a theory for how we design and simulate reality; and criticized the aspects of consumer culture that was shaped after post-modernity in his book "Simulacra and Simulations," published in 1981. Since society has become so reliant on signs, symbols, and models, as post-modernism suggested, reality has started to imitate the signs. The signs have replaced reality and determined the world. The active replacement of reality is called simulation: "Simulation is no longer a referential being or a substance. It is a generation by models of a real without origin or reality: a hyperreality" (Baudrillard, 1983: 2). According to Baudrillard, simulation is the process through which reality is usurped. Then, the produced system of simulation is 
a simulacrum, a copy without an origin. The mass production and manipulation of images by photography, motion pictures, and afterward, media culture, along with multinational capitalism, provided the basis of hyperreality:

"Of the same order as the impossibility of rediscovering an absolute level of the real is the impossibility of staging an illusion. The illusion is no longer possible because the real is no longer possible. It is the whole political problem of the parody, of hyperstimulation or offensive simulation, which is posed here (Baudrillard, 1994: 19)."

For developing his theory of hyperreality, he used Lascaux II as an example. Lascaux II is the exact copy of the original Lascaux cave built by the French government to prevent the destruction of Lascaux cave caused by visitors.

"In this way, under the pretext of saving the original, the caves of Lascaux have been forbidden to visitors. A replica is constructed 500 meters away so that everyone can see them (you glance through a peephole at the real grotto and then visit the reconstituted whole). It is possible that the very memory of the original caves will fade in the mind of future generations. Still, there is no longer any difference from now on: the duplication is sufficient to render both artificial (Baudrillard, 1983: 18)."

The cave has, in fact, two other copies today. For instance, Lascaux IV, the latest replica, was opened to the public in 2016. While visitors' experience in Lascaux II is passive, Lascaux IV is designed to increase visitors' interaction by using new media tools or "toys." While the design of Lascaux IV enhances Baudrillard's concept of simulacra, it also reflects the idea of McLuhan's post-modernist "Global village."

\section{PROCESSUAL ARCHAEOLOGY}

Around the 1960s, a new archaeological movement called processual or new archaeology has emerged due to efforts, especially by Binford. He was inspired by Caldwell's idea of cultures as functionally integrated systems and his support for neo-evolutionary anthropology published in an article titled "The New American Archaeology" (Trigger, 2007: 392).

The purpose of new archaeology was to understand the reasons for the formation of the archaeological record by using scientific methodology. Timothy K. Earle and Robert W. Preucel (1984: 501) described processual archaeology as underlying its scientific perspective:

"Positivism was modeled upon the scientific method then in use in the natural and social sciences. Consequently, new archaeology stressed theory formation, model building, and hypothesis testing to search for general laws of human behavior. Perhaps its most important contribution was its focus on cultural process rather than cultural history."

Other aspects of processual archaeology are behavioral archaeology, ethnoarchaeology, and experimental archaeology, which were applied to find analogies to explain material remains and interpret the past based on archaeological data. Binford suggested that the ultimate goal of archaeological studies should be to elucidate the dynamics of a social group to produce a middle-range theory (Binford 1962; 1968; 1978; 1981). While arguing for archaeology's broader contribution to anthropology, he implied that the main factor of the poor connection was the tendency of archaeologists to treat material remains as equal and comparable traits regardless of their context.

The major distinction between "old" and "new" archaeology was their definition of "culture." In old archaeology, culture was defined according to the normative perspective and was related to ethnicity, migration, and diffusion (Earle and Preucel, 1987: 502, 503). This perspective allows the enthusiasm of classification, taxonomy, and chronology of material remains to provide an interpretation of the past. In the 1960s, culture meant sociological, technological, and ideological characteristics of human 
behavior (Watson, 2008: 29). Changes in material culture were recognized as a reflection of ecological adaptation (Trigger, 2007: 309). New archaeologists were concerned with the mechanisms of the cultural process and applied scientific methods to elicit general laws on human behavior.

\section{POST-PROCESSUAL ARCHAEOLOGY}

During the $1970 \mathrm{~s}$, the meaning of culture shifted to the sense in which culture referred to "cognitive universes constructed and maintained by groups" (Watson, 2008: 30) and "as a source of crossculturally idiosyncratic variation in human beliefs and behavior" (Trigger, 2007: 444). By this time, a new archaeological approach called post-processual archaeology was developed. Trigger sustained that the new understanding of culture was touched by several contemporary intellectual movements, including social anthropology inspired by neo-Marxism and post-modernism (2007: 444-449).

Marxist anthropologists rejected previous ideas of culture and cultural ecology shaped by neoevolutionism and structuralism. They favored a human-centered view of the dynamics of culture. Post-processual archaeology emerged around the 1980s by Ian Hodder when he and his students attempted to apply Marxist anthropologists' ideas to archaeological studies (Trigger, 2007: 450). Postprocessual archaeologists focused on specific cultural histories, the material culture identified as symbols in social strategies and contextual analyses (Thomas, 2015: 1288). They emphasized individualism and the human role in the organization of society and culture: "They denied that unbiased, unproblematic, objective access to "the real past" is possible" (Watson, 2008: 33).

In the chapter titled "Post-modernism, post-structuralism and post-processual archaeology" from "The Meaning of Things," Hodder described the era as "the birth of a new cultural style" in 1989 and said that "it is thoroughly engrossing for an archaeologist, a student of cultural change" to live in this era (1989: 65). Referring to post-modernism, he mentioned Mark Boyle and a group of artists expressed as the Boyle family in 1985. Hodder cited Mark Boyle's doubt on the relation between art and interpretation, which was also represented in his work on making an exact copy of the world. $\mathrm{He}$ compared this work of digging out the environment with what an archaeologist does. At the end of the chapter, he once again recalled the Boyle family regarding the organization of the chapters in the book:

"It, therefore, becomes necessary to write this book in a way that criticizes and limits at least certain dimensions of power. I have taken my cue from the Boyle family. I wish to create this book as just another image, containing many images within it, which can be read in many ways. The aim is to return the meaning to the reader who must work at creating his or her own meaning out of diverse contributions (1989: 77)."

Ian Hodder was probably the first archaeologist who followed and was inspired by contemporary conceptual approaches in art. He considered the essence of humans, looked at other perceptions about the meaning of material culture that humans created either now or in the past, and adopted them for archaeological interpretation. Because of him, post-processual archaeology was entirely different from other archaeological theories. As the notion developed through time, it appeared that the most significant outcome of post-processual archaeology was its contribution to integration and diversification of archaeology with respect to material culture studies.

The post-processual archaeological movement had a reflection on ethnoarchaeological studies with a new focus on the relation between the meaning and the social role of the materials (Preucel and Hodder 1996). This process is now called contemporary archaeology. However, the definition of contemporary archaeology is also argued, and it is suggested that what it refers could be called the archaeology of today (González-Ruibal, 2014: 272).

Victor Buchli and Gavin Lucas have described the contemporary past as a critical intervention applied using traditional archaeological methods to reveal new orders of knowledge about recent history 
(2002). To establish a borderline between historical archaeology and contemporary archaeology, Rodney Harrison and John Schofield adopted the definition provided by Charles E. Orser (2010: 48). Orser suggested that historical archaeology is a multidisciplinary field concerning anthropology and history, focusing on the post-historic past and finding out more about the nature of modern life.

Various authors have defined the distinction of the contemporary or recent past as being about the themes, rather than temporal distance. If we accept the role of archaeology both for remote or recent past, then archaeology is the tool for understanding and interpreting the material remains to reconstruct a narrative and genealogic history of humanity. At this point, Harrison and Schofield underlined that, as there are fewer competing narratives, it is easier to create the past when someone stands far away in time (2010: 50). Then they examined the differences distinguishing contemporary archaeology from other disciplines, which shares the interest in material culture and the recent past.

\section{CLOSE ENCOUNTERS OF THE THIRD KIND}

\section{NEW TRENDS IN EXHIBITION AND DISPLAY TECHNIQUES OF MATERIAL CULTURE}

Museum as described by ICOM, "... is a non-profit, permanent institution in the service of society and its development, open to the public, which acquires, conserves, researches, communicates and exhibits the tangible and intangible heritage of humanity and its environment for education, study and enjoyment."

Nevertheless, the meaning of the museum has been radically changed over time. The alteration in the behavior of museums is a reflection of developments in art, technology, economy, and politics. Besides their role of preserving cultural heritage values with cultural, artistic, historical, or scientific significance, museums are the institutions that develop an interdisciplinary understanding of material culture studies.

The first public museums were opened in 1683 when English antiquary Elias Ashmole donated the contents of his collection to Oxford University, forming the groundwork of the Ashmolean Museum. It was followed by the foundation of the British Museum in 1759, the Prado Museum in 1785, and the Louvre in 1793. Close to the definition given above, the intent of these museums was to make private the collections accessible to the public and educate them through cabinets of curiosities. The visitors were merely vast audiences who watched and appreciated the beautiful artworks and archaeological objects in chronologic order.

By the 20th century, the vast developments and changes in history led to new artistic movements and post-modernism that brought radical freedom to art, required new architectural spaces and plans for exhibitions. In the 1980s, post-modern discourse affected the architectural style. Instead of the abstract structural interaction of modernism, exhibition areas now reflected the physical and conceptual characteristics of post-modernist movements. Post-modern ideas for exhibitions provided the audience with the opportunity to experience the space, enhancing the perception by various design elements such as light and sound, besides the objects on display. "Art, as a consumption area for the wealthy, was isolated from the remaining part of Western societies. Contrary to that tradition, New Museology remains closer to the needs of various communities. Rather than being an elitist domain, it encourages a dialogue with the diverse audience" (Wieczorek, 2015: 20). Therefore the difference in architecture, along with the developing technologies, has given audiences new independence. The museum's role has shifted from monumental and static institutions to more dynamic and experiential public spaces (Greenberg, 2005: 226).

Investments in art and financial supports to exhibitions by leading companies developed management and marketing in museology in the 1980s (Boratav and Gürdal, 2016: 177). Meanwhile, post-modern urban planners intended to integrate previously separate elements and return to a better-socialized environment while distracting society (León, 2017: 58-60). In the post-modern city, which depends on 
the association between symbols and signs, museums are placed in the center of the culture and tourism industry. Although museums are non-profit institutions, to attract sponsors and keep their role as public spaces in urban life, the number of visitors gains importance. Therefore, museums need to discover new ways and attractions to be distinguished from their counterparts. In the "Communicating the Museum 2015" conference held in Istanbul, Corinne Estrada indicated that museum communication's most critical parameter was how the museums displayed their collections. She suggested that museums should apply new technologies to their exhibition design concept since "the way you" display is more important than "what you display" according to current trends in entertainment. Museums need to think about mostly young visitors because the communication tools of the new generation are now strikingly different and largely depend on visual recognition. Besides tourism purposes of visit, museums should consider attracting local people and support regular social events.

Today museums are developed as one of the most popular tools of mass communication. The exhibition strategies change visitors' behavior by encouraging them to interact with objects and spend more time within the museums and use different senses to understand the narratives of the objects. Visitors have become active agents, and events on display depend on interaction. Traditional objectbased understanding of display where the artworks were untouchable and noble is evolved, and the relation between the visitor and the object is transformed. As visitors have become users, museums should provide innovative ways, adopt changes in technologies, and use social media.

Using digital techniques makes it possible to reconstruct the past according to various interpretations. Digital media, with the help of interdisciplinary approaches, provide limitless possibilities for preserving, monitoring, representing, and managing cultural assets.

Lascaux IV is an exceptional model of contemporary technology-driven exhibition techniques. Within the cave, The Lascaux Studio, the space reserved for representing the cave's major works, offers four different displays, including "the model, the art experience, the fragile balance, and the Lascaux objects." In the art experience part, visitors take in the opportunity to create their works of art virtually using Palaeolithic tools and techniques. Meanwhile, in the Lascaux Objects, visitors can touch the things found during the excavations and learn more about them by watching a video.

\section{ARCHAEOLOGICAL ART OR ARTISTIC ARCHAEOLOGY}

In 2003, Colin Renfrew published a book titled "Figuring it out: the parallel visions of artists and archaeologists." So, he became the leading archaeologist who invited artists and archaeologists to gain a lot from close collaboration and interaction. He explored contemporary movement on displaying objects, on the installations of conceptions, and the aesthetics through artists including Mark Dion, Antony Gormley, Richard Long, Andy Goldsworthy, David Mach, and Eduardo Paolozzi. His interesting thoughts were probably more convincing and inspirational for archaeologists since what Renfrew did was basically to open a new perception for archaeological representation and interpretation.

Later on, the 6th World Archaeological Congress was held in 2008. One of the sessions in Congress was on "Archaeologies of Art." The aim of the theme was described as encouraging closer encounters of art and archaeology to provide the participation of two disciplines.

The articles of this session included "Art to Archaeology to Archaeology to Art" by Douglass Bailey, "Dust and Debitage: An Archaeology of Francis Bacon's Studio" by Blaze O'Connor, "Art and Archaeology: Reflections of an Artist/Curator" by Kevin O'Dwyer and "Archaeoclash: Manifesting Art and Archaeology" by Andrew Cochrane and Ian Russell. Here, we would wish to focus more on the article by Douglass Bailey. He discussed the series of relations between artists and archaeologists. As the title explains, he began with the artists. His reviews of the artists involved Mark Dion, Simon Callery, and Richard Long for understanding the types of interaction between the two fields. Bailey 
presented Mark Dion as an artist who is inspired by archaeology. Mark Dion's works indeed have a strong resemblance with artworks that used found objects to understand the cultures they belonged. Bailey argued that his works are not archaeological and appraised Dion's approach being almost pranked archaeology or imitation of archaeology. Then, he discussed Callery's installation called "Trench 10" and related him to archaeologists since he also deals with time, landscape, material culture, and displaying them. Bailey mentioned Long's photograph on the flattened turf caused by action and time as an archaeological concept. According to Bailey, for the last decade, archaeologists looked to contemporary artworks as sources of analogies and interpretive information. It could be supposed that this trend was initiated with post-processual archaeology. However, Ian Hodder, who expressed that his motivation aroused by post-modernist art, has had another objective. He embraced the contemporary discourse to provide "meaning" and "representation of culture" to archaeology.

In the following part, he turned to the archaeologists, like Alfredo Gonzales-Ruibal and Bjornar Olsen, who visualized abounded places in an archaeological sense. Bailey then described the study led by John Schofield on contemporary archaeology. The work was to establish an archaeological excavation on a minivan used for transportation. Although the work was a scientific investigation, Bailey compared its impact with the contemporary artwork's effect on visitors.

Bailey also mentioned Michael Shanks and his visual works. Michael Shanks is an outstanding example of archaeologists who shared common concerns with Ian Hodder about the interpretation of archaeology and, accordingly, the interpretation of cultures. Bailey considered his works: "Michael's work engaged in a wide range of experiments about pushing away from traditional understandings of how archaeologists should represent the past, especially in pushing away from ideas of simple narrative and historical reconstruction."

"The representation of the past" maybe explains the true nature of the interaction between art and archaeology. Contemporary archaeologists apply artistic discourses to find analogies and find alternative ways to understand what culture is and the human agent's role in representing or reconstructing the past.

In the end, Bailey concluded that there was no distinction between art and archaeology. According to him, both disciplines are concerned with "what it means to be human." Mainly because of the archaeological movement of the contemporary past, he believed that the artists and archaeologists would benefit from juxtapositioning usually separated things.

Julia Sorrell wrote her consideration on uniting art and archaeology from her artistic perspective in her study called "Art and Archaeology: The visualization of Orkney" (2016). Because she was requested to establish an exhibition of Orkney's paintings, she tried to find an alternative through art to appeal to archaeologists or academics and people from different backgrounds. Sorrell traced the struggle of a group of artists, including Paul Nash and her father, Alan Sorrell, in the late 1930s for creating collaboration between art and archaeology (2016: 1-2). When she pointed up the differences between artists' perceptions from archaeologists' expectations, she marked the dilemma of visual reconstruction of archaeology and interpretation. The theme was also discussed in various articles, such as studies representing the archaeological reconstruction by artists (Perry and Johnson 2014) and new media technologies (Muşkara 2017).

In recent work, Christopher Smith evaluated the interaction between archaeology and art (2016). He mentioned the metamorphic significance of archaeology, which was also noticed by Foucault in "Archaeology of Knowledge" (1969) as a methodology for "digging down through layers" (2016: 272273). He went through two case studies to indicate the use of archaeology for different kinds of narratives. One of them relating to Queen Puabi especially bears importance to the main idea of this study. The exhibition called "From Ancient to Modern: Archaeology and Aesthetics" was organized by the Institute for the Study of the Ancient World (ISAW) in 2015. 
The introduced works were exemplary of modern and contemporary approaches made by Alberto Giacometti, Willem de Kooning, Charles Olson, and Michael Rakowitz to illustrate the influence of prehistoric objects on the modern aesthetic consciousness.

Another exhibition, titled "Prehistory, A Modern Enigma" at Centre Pompidou (2019), shares similar concerns. The intent of the exhibition is explained to show the link, which unites prehistory to modern and contemporary art (Debray, Labrusse and Stavrinaki, 2019: 6). In the search for the invention of the concept of prehistory and its effects on modern perception, the exhibition hosts work by artists from the 1930s to 1980s and concluding with a contemporary part including Max Ernst, Alberto Giacometti, Joan Miró, Pablo Picasso, Joseph Beuys, Louise Bourgeois, Dove Allouche, Jennifer Allora, JeanPascal Flavien, Dov Ganchrow, Christian Jaccard, Christian Kerez, and Richard Long.

Smith considered the exhibition by ISAW as post-modern for being within a self-reflexive matrix and a new way or an arrangement to attract the visitors (2016: 274). He also connected this exhibition with the ideas of Shanks and Tilley regarding splitting artefacts from chronological narrative and original contexts and reassembling them with contemporary artefacts (2016: 280).

Likewise, the room called "The Imaginary Gallery" in Lascaux IV is dedicated to a temporary exhibition designed by Jean-Paul Jouary to explore the connections between various artworks from cave art to contemporary art artists such as Miró, Tapies, Kandinsky, and Picasso. The design also provides interactive exhibitions to be curated by visitors and displayed or posted up on a shared public wall in the gallery.

\section{“GÖBEKLITEPE, ZERO POINT IN TIME" AND “THE CURIOUS CASE OF ÇATALHÖYÜK”}

Göbeklitepe is located in southeastern Turkey between the Tigris and Euphrates rivers in Northern Mesopotamia. It was a complex for ritual activities and dated approximately 12 thousand years ago. Discoveries at Göbeklitepe revealed that the site reflects the economic and social transformation from hunting and gathering to agricultural. The complex social systems of people in Göbeklitepe are demonstrated well by the monumental buildings. Besides the importance of archaeological data, the public interest make Göbeklitepe one of the most important discoveries in the history of archaeology.

Klaus Schmidt started the excavations in 1995; however, after his sudden death, they are extended by the German Archaeology Institute and the Republic of the Turkey Ministry of Culture and Tourism. The construction of the Göbeklitepe Visitor and Animation Center was initiated in 2015 to host the increasing number of visitors. Architects Aydan Volkan and Selim Cengiç, inspired by the "T" shaped pillars and circular architecture of Göbeklitepe, developed the design concept. Visitors are introduced to the animation center to have the necessary information on Göbeklitepe before entering the site (Fig. $1)$. 


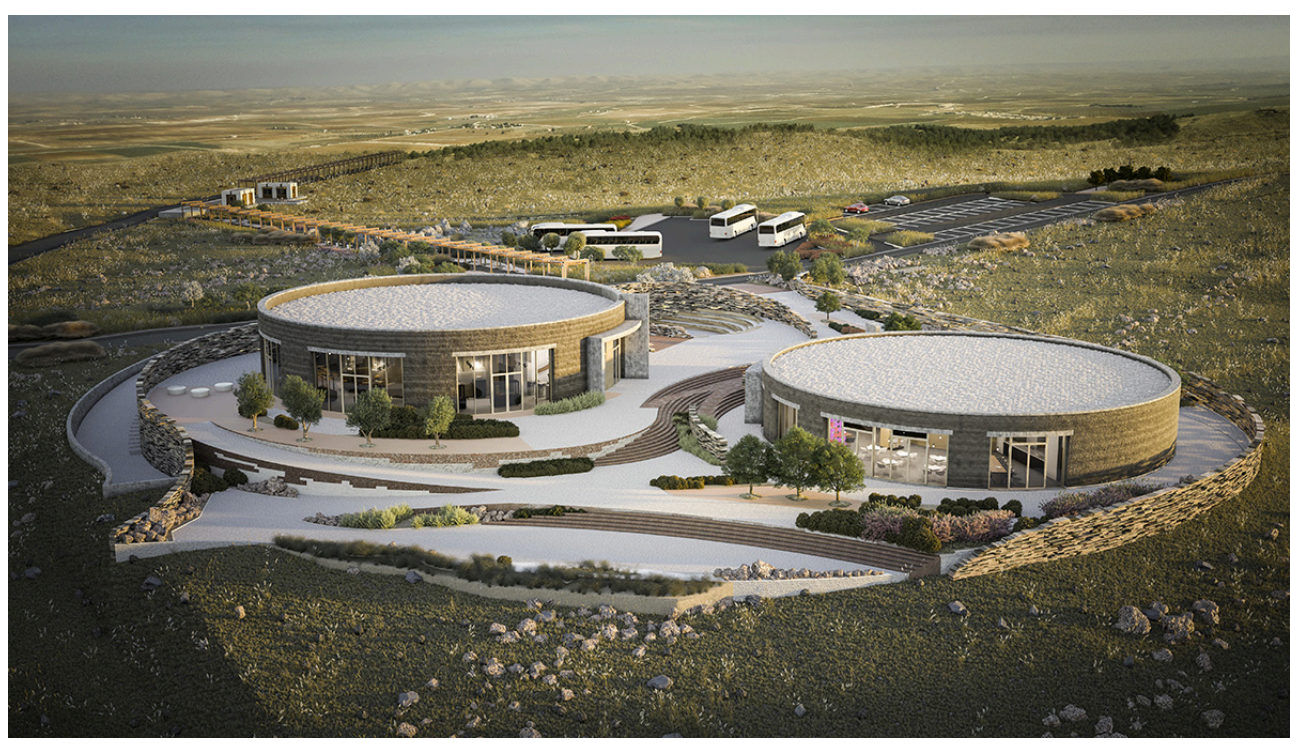

Figure 1. Göbeklitepe Visitor and Animation Center (https://kreatifmimarlik.com/project/gobeklitepeziyaretci-ve-canlandirma-merkezi/)

The center is divided into three halls. The main hall is designed to reflect images of the excavation area using interactive screens (Fig. 2). Some objects found during the excavations are also displayed, along with the diaries and excavation notes of Klaus Schmidt and newspapers about Göbeklitepe. Small holes placed on the sides provide images relating to the site (Fig. 3). Indeed, the holes provoke curiosity and require visitors to "dig" layers. This arrangement in the main hall supports visitors to feel like archaeologists and are exploring Göbeklitepe.

In one of the halls, a documentary on Göbeklitepe produced by National Geographic is shown on screen (Fig. 4). While visitors understand the history, the architecture, and importance of the site, they also make acquainted with the notion "Zero Point in Time" about Göbeklitepe.

The most impressive hall is dedicated to people who lived on the site. In a semicircle-shaped area, visitors encounter a ritual constituted of images, sound, light, and music using the scene of Göbeklitepe (Fig. 5). Because the project is reflected extensively on the walls, visitors experience the virtual reality of Göbeklitepe even without using glasses or goggles. The features that attract various senses, including sight, hearing, and touch, draw visitors mentally and physically to the spiritual environment. 




Figure 2. The interactive screen

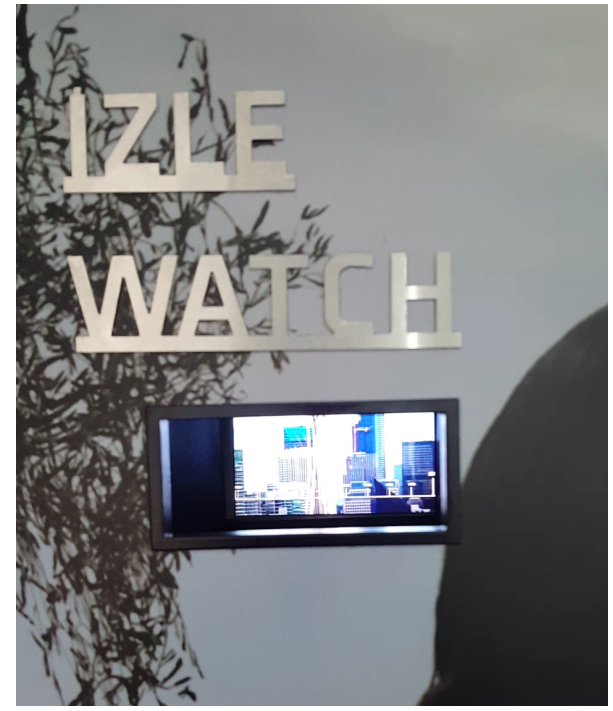

Figure 3. The hole for watch inserted into the wall

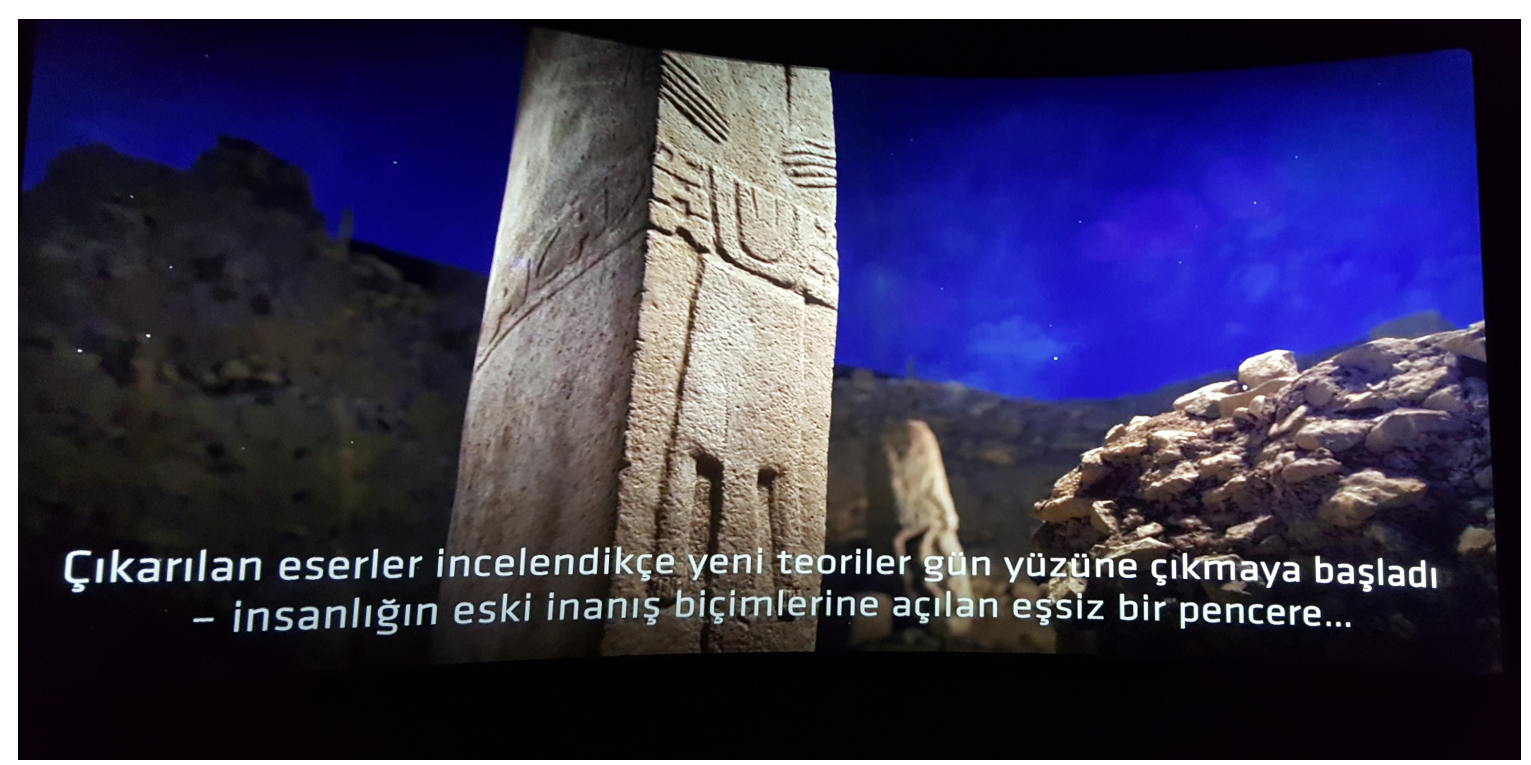

Figure 4. A screenshot form the documentary of Göbeklitepe produced by National Geographic 


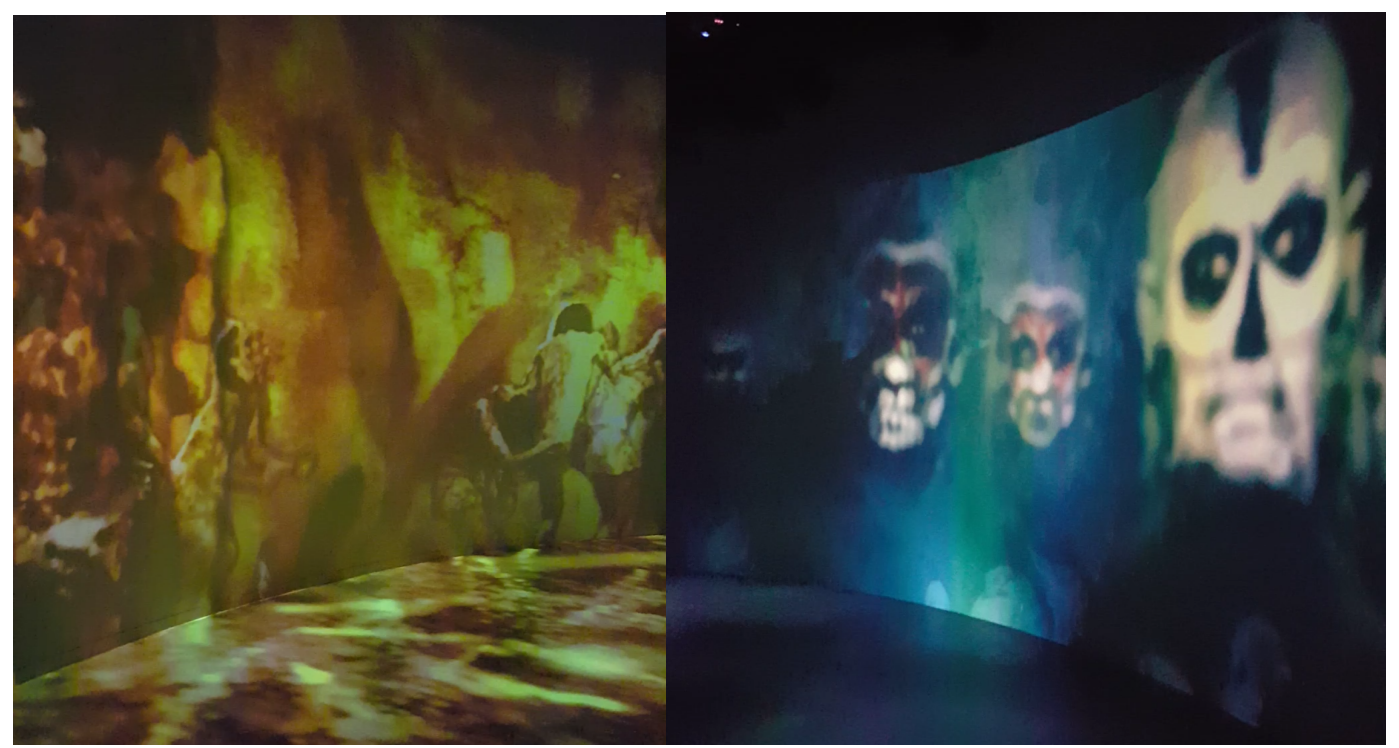

Figure 5. The video representing a ritual at the animation center

Meantime, Çatalhöyük is a Neolithic settlement located in central Turkey. The site has been excavated since the 1960s. The first scientific studies in Çatalhöyük were carried on under the supervision of James Mellaart until 1965, and then in 1993, Ian Hodder carried on the excavations. Çatalhöyük is an extraordinary archaeological site, and it could be considered the core of the post-archaeological approach. The post-processual archaeological methodology and its interpretation of material culture entangled with people have been spread out from Çatalhöyük. Likewise, the research project of Çatalhöyük is significant for its support for collaboration between different disciplines and the application of new technologies.

"The Curious Case of Çatalhöyük" was organized to celebrate the 25th excavation season of the Çatalhöyük. The exhibition designed under Ian Hodder's supervision and curated by Duygu Tarkan is indeed the narrative of archaeological studies, which visualizes the various stages of an excavation project from the first step of digging documentation and analysis of the archaeological finds. The exhibition also aims to underline the legacy of the Çatalhöyük team on being innovative and supporting the international collaborations: "Çatalhöyük is presented through experiment-based display features including 3D prints of finds, laser-scanned overviews of excavation areas, and immersive Virtual Reality (VR) opportunities that bring the 9000-year-old Çatalhöyük settlement back to life" (Anamed 2017).

The exhibition area was designed as an excavation house where archaeologists work on the material remains, and visitors could observe how archaeologists work. It is as if visitors enter the empty place where archaeologists take a little break (Fig. 6). However, on a screen, they encounter Ian Hodder, who mutually answers their questions. 


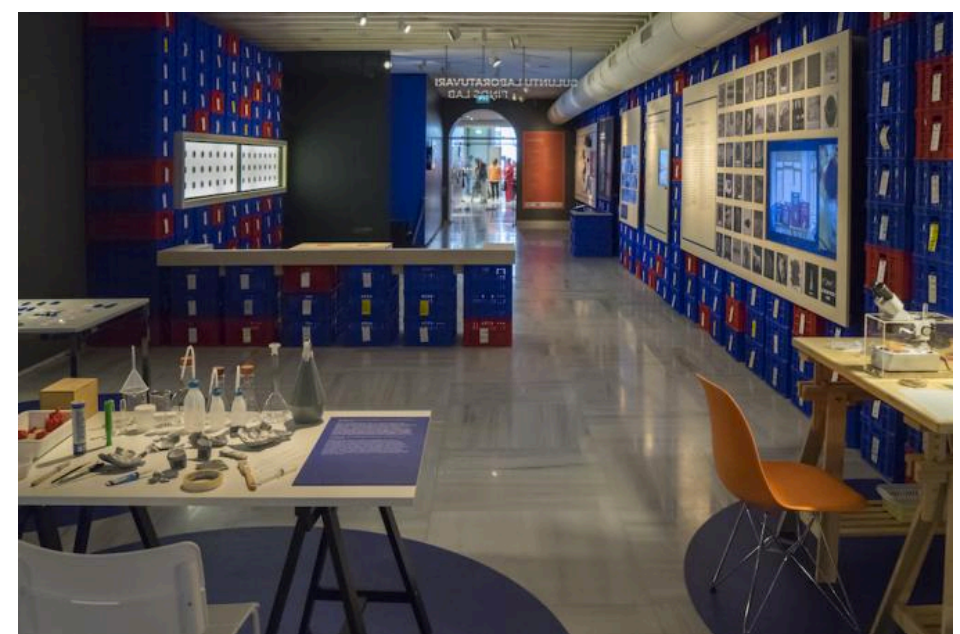

Figure 6. The area designed as archaeologists' work place (https://anamed.ku.edu.tr/events/bir-kazihikayesi-catalhoyuk/)

Referring to art and archaeology collaboration, digital installation "Çatalhöyük Research Project Archive" by Refik Anadol could be defined as the encounters of the third kind (Fig. 7). Anadol developed this impressive installation by using 2.8 million data obtained from 250.000 archaeological remains:

"We need to consider that this project involves machine-learning algorithms for the re-evaluation of all Çatalhöyük data corresponding roughly to a 25-year time frame. During this project, relying on source codes, we have attempted to re-evaluate about half a million pieces of data we had at hand, which consisted mostly of images. We eventually started to question if a network of this complexity could be perceived in a simplistic fashion. If it is indeed possible, we wanted to know if a sculpture or a poetic approach could be extracted from it. The data available in the archive is so immense that it could fill thousands of square meters. Questioning the nature of data, whether it could have a physical counterpart; about how much space 25 years of discussions and thought would occupy; about how many pages it would include if printed as a book. This project reveals itself as a translation into the physical plane. For instance, as we consider how such a complex entity would be seen by outsiders to the Çatalhöyük team, we see the machine intelligence is, in fact, a major advantage. I would guess that the smaller and more complex structures in between provide colossal clues to researches at the macro and micro levels. In other words, at present, it is only a digital, abstract and virtual approach. Yet, in the future, researchers can use such complex and vast data collection to their advantage (Anadol, 2017)."

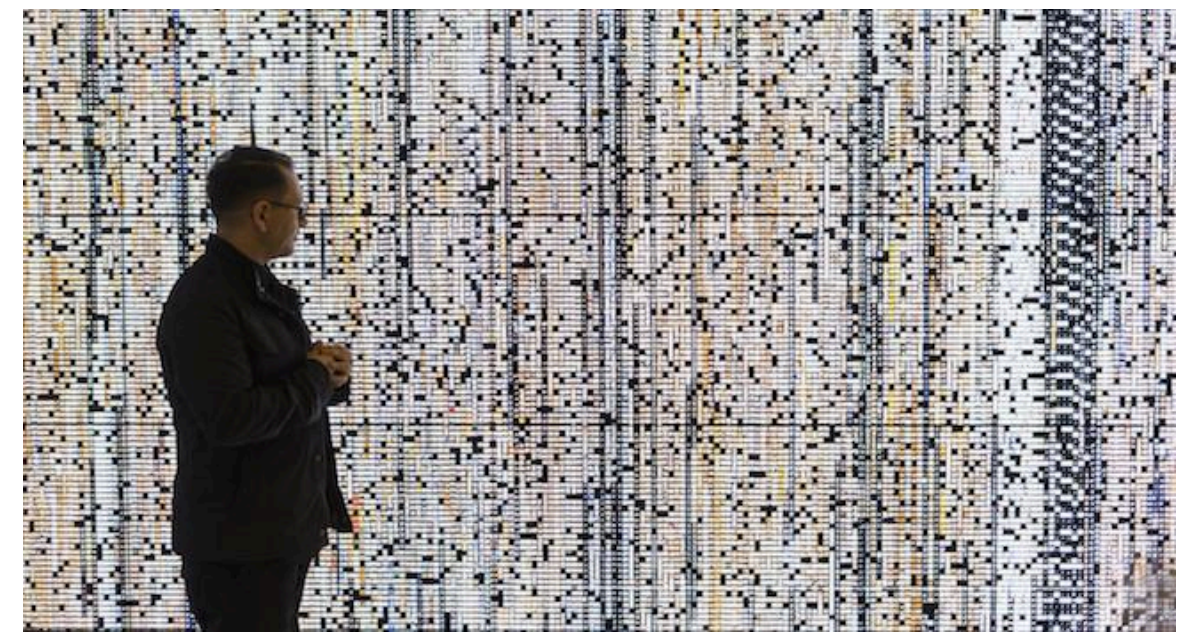

Submit Date: 13.01.2021, Acceptance Date: 10.03.2021, DOI NO: 10.7456/11102100/024

Research Article - This article was checked by iThenticate

Copyright (C) The Turkish Online Journal of Design, Art and Communication 
Figure 7. The installation by Refik Anadol "Çatalhöyük Research Project Archive" (https://anamed.ku.edu.tr/events/bir-kazi-hikayesi-catalhoyuk/)

Anadol's idea of digital data interpretation provides both the visualization of archaeological materials and archaeology itself. The installation is; indeed, the visual interpretation of Çatalhöyük orbits around the material remains. Anadol also offers a new way for archaeologists to connect and interpret the vast amount of data. "Çatalhöyük Research Project Archive" is perhaps one step further searching for meaning beyond the objects for post-processual archaeologists. It visualizes objects within a system or entanglements, but not as in art-historical sense as we have seen in old archaeology's tradition. The installation also represents the current status of the relation between art and archaeology, which provokes its audiences to recognize culture in a broader sense.

\section{CONCLUSION}

The history of the relationship between art and archaeology goes long back since both disciplines are closely tied to material representations of cultural aspects. Nevertheless, the first interaction occurred in the dawn of post-modernism simply as an inspiration of artists by prehistoric objects and rituals. The Age of Reason emphasizing logic and science was rejected in Dadaist Disgust while it was triggered the emergence of archaeology. In the meantime, processual archaeology improved the quantitative and scientific characteristics of archaeological interpretation.

In the era of post-modernism, archaeology has extended its perception for the meaning of culture. Embodied in Ian Hodder and post-processual archaeology, archaeologists have collaborated with contemporary art. Some considered visual art as a new source for interpreting the past, while others recognized the artistic side of archaeology. By the 21st century, academic research and exhibitions that revealed the conceptual framework of interaction between art and archaeology have sharply increased.

As Colin Renfrew suggested, archaeology should be fun as contemporary art; the true nature of the interaction between art and archaeology may be concealed under the method of representing the past. As art for everyone, archaeologists realized that archaeology is supposed to be everyone to understand. Thus, many museum displays consist of contemporary design features by employing digital media and applying the concepts of contemporary art. Therefore, visitors who have become users could experience ancient cultures and their lifestyles through visual and auditory perceptions and tactical sensing through digital applications. At the same time, they reach historical and cultural information. The visitor or the user is no longer the person who obtains knowledge only intellectually but transformed into the person who exists in the surrounding of a specific culture; even it is created virtually. Today, considering technology is an extension of the human body, art and archaeology mostly encounter by digital approaches. The change in the viewing of the new generation mostly depends on visual perception, and their use of digital games encourages such a relationship.

Çatalhöyük exhibition and Göbeklitepe Animation Center are considered to be among the best examples of the new approach in archaeology. The team of Çatalhöyük, as a school for postprocessual archaeology that underlines the importance of the meaning of "archeological things," designed the exhibition "Curious Case of Çatalhöyük" for the users to learn and experience the way an archaeologist explore the narratives of the past. Because the design focused on the archaeologist and the archaeology, users understand how archaeology works, and with Anadol's installation, the years of work and the quantity of data to reconstruct a Neolithic site. In the Göbeklitepe animation center's design, digital tools were applied for reconstruction of how the society at the beginning of the Neolithic revolution gathered and built the circler structures and why they needed such an organization. Before entering the actual site, visitors are able to visualize and experience Göbeklitepe not merely as an archaeological remaining but also as a place once people lived. It is provided to users not in a simulated space because the real Göbeklitepe is in proximity to explore with well-prepared info-graphics. Especially Anadol's installation to visualize archaeological data opens a new era of 
archaeological reconstruction. It is also crucial to realize that such digital and interactive presentations should involve mutual understanding between art and archaeology as in the Çatalhöyük exhibition and Göbeklitepe to prevent Baudrillard's concerns about the simulation of reality.

\section{REFERENCES}

Anadol R (2017) https://anamed.ku.edu.tr/refik-anadol-catalhoyuk-arastirma-projesi-arsivi/

Antmen A (2009) 20. Yüzyil Batı Sanatında Akımlar (Sanatçılardan Yazılar ve Açıklamalarla). Sel Yayincilik.

Anamed (2017). https://anamed.ku.edu.tr/ Koç Üniversitesi Anadolu Medeniyetleri Araştırma Merkezi

Arnold B and Wicker NL (2001) Gender and the Archaeology of Death. New York: Rowman Altamira.

Bailey DW (2014). Art // archaeology // art: letting-go beyond. I. Russell and A. Cochrane (eds), Art and Archaeology: Collaborations, Conversations, Criticisms. New York: Springer-Kluwer: 231-520.

Bapty I and Yates T (1990) Archaeology After Structuralism: Post-structuralism and the Practice of Archaeology. New York: Routledge.

Baudrillard J (1983) Simulations. New York, NY: Semiotext(e).

Baudrillard J (1994) Simulacra and Simulation. University of Michigan Press.

Binford LR (1962). Archaeology as Anthropology. Cambridge: University Press.

Binford L (1968) Methodological considerations in the use of ethnographic data, in Lee RB and De Vore I (eds.) Man the hunter. Chicago: Aldine Publishing Company, 268-273.

Binford L (1978) Nunamiut ethnoarchaeology. New York: New York Academic Press.

Binford L (1981) Middle-range research and the role of actualistic studies, in Bones: ancient men and modern myths, New York Academic Press, New York, 21-30

Boratav O and Gürdal N (2016) 1980 Sonrası Sergileme (Exhibition After 1980) Art-Sanat Dergisi (6): 169-183.

Buchli V and Lucas G (2002). Archaeologies of the contemporary past. New York: Routledge.

Debray C, Labrusse R and Stavrinaki M (2019) La préhistoire : Une invention moderneby Collectif. Bibliothèque publique d'information du Centre Pompidou.

Elder B (2015) Dada, surrealism, and the cinematic effect. Ontario: Wilfrid Laurier Univ. Press.

Earle TK and Preucel RW (1987). Processual archaeology and the radical critique. Current anthropolog 28(4): 501-538.

González-Ruibal A (2014). An archaeology of resistance: Materiality and time in an African borderland. New York: Rowman \& Littlefield.

Greenberg S (2005). The vital museum: Reshaping Museum Space. Architecture, Design Exhibitions, 226-237.

Harvey D (1989) The condition of post-modernity. Cambridge and Oxford: Blackwell.

Harrison R and Schofield J (2010). After Modernity: Archaeological Approaches to the Contemporary Past. Oxford/New York: Oxford University Press

Hodder I (1989) The Meaning of Things. London: Routledge.

ISAW (2015) http://www.nyartbeat.com/event/2015/B280 
León BB (2017). Urban theory in postmodern cities: Amnesiac spaces and ephemeral aesthetics. Revista de Estudios Urbanos y Ciencias Sociales 7(1): 57-65.

Lyman RL and O'Brien M (2004) History and Explanation in Archaeology. Anthropological Theory 4(2): 173-197.

McLuhan M (1962). The Gutenberg Galaxy, Toronto: U Toronto P.

Merton RK (1949). On sociological theories of the middle range.

Muşkara Ü (2017) Yeni Medyanın Kültürel Miras Konulu Uygulamaları. Erdem 73: 89-110.

Olsen B (2012) After interpretation: remembering archaeology. Current Swedish Archaeology, 20:1134.

Özendes E (2017) Osmanlı İmparatorluğunda Fotoğrafçılık. İstanbul: Dekar yayınevi.

Perry S. and Johnson M (2014). Reconstruction art and disciplinary practice: Alan Sorrell and the negotiation of the archaeological record. The Antiquaries Journal 94: 323-52.

Preucel R and Hodder I (1996) Contemporary Archaeology in Theory. Oxford: Blackwell.

Renfrew C (2003) Figuring It Out: The Parallel Visions of Artists and Archaeologists. London: Thames and Hudson.

Schnapp JT, Shanks M and Tiews M (2004) Archaeology, modernism, modernity. Modernism/modernity 11(1): 1-16.

Smith C (2016). Beyond metaphor: archaeology as a social and artistic practice. Journal of Visual Art Practice 15(2-3): 270-285.

Sorrell J (2017). Art and archaeology: the visualisation of Orkney. Antiquity, 91 (356).

Şahiner R (2008) Sanatta Postmodern Kırılmalar. İstanbul: Yeni İnsan Kitabevi.

Thomas J (2015) The future of archaeological theory. Antiquity 89: 1277-1286.

Trigger B (2007) A History of Archaeological Thought. Cambridge: University Press.

Watson PJ (2008) Processual and After, in Bentley RA, Maschner HDG and Chippindale C (eds) Handbook of Archaeological Theories. New York: Rowman Altamira.

Wieczorek M (2015). Postmodern Exhibition Discourse: Anthropological Study of an Art Display Case. Journal of Science and Technology of the Arts 7(2): 19-24.

Woods Dick L (1984) Art and political ideology: The Bauhaus as victim. MA Thesis, Kansas State University, USA.

Zamorano G (2011) Traitorous Physiognomy: Photography and the Racialization of Bolivian Indians by the Créqui-Montfort Expedition (1903). The Journal of Latin American and Caribbean Anthropology 16(2): 425-455. 